\title{
Problems Students Face in Translating Discourse Markers from English into Kurdish
}

\author{
Haneen Islam Saleem ${ }^{1}$ Hakar Hazim M.Ameen ${ }^{2}$ \\ ${ }^{1}$ Department of English, College of Languages, University of Duhok, Kurdistan Region, IRAQ \\ ${ }^{2}$ Department of Translation, College of Languages, University of Duhok, Kurdistan Region, IRAQ
}

\begin{abstract}
This paper investigates the problems are found in the translation of discourse markers from English into Kurdish. One of the main problems that discourse markers cause for translators is that discourse markers may have various possible translation choices. Moreover, a discourse marker has many functions, i.e. it may have more than one function. It can be thus used to show a variety of relations between several written discourse parts. Accordingly, a translator has to decide the function that a discourse marker has in a definite context to give the correct translation. In this paper Fraser's Model of discourse markers analysis (1999) has been chosen for investigating discourse markers. As for the data analysis, four students of the Department of Translation at the University of Duhok have been chosen to translate the same text from English into Kurdish to show the difficulties in choosing the correct discourse markers in these four different translations. The results showed that there are no equivalents in choosing the correct discourse markers when translating them into Kurdish.
\end{abstract}

Keywords: Discourse markers, Grammatical category of discourse markers, Factions of discourse markers, Discourse markers in Kurdish, Fraser's (1999) Model.

\section{Introduction}

Discourse markers, henceforth (DMs), have long been the fundamental concern in pragmatics, referring to those elements in a discourse that shows practical meaning and help to communicate intentions. Linguists have assigned various terms to this linguistic phenomenon such as pragmatic expressions, cue words, discourse markers, discourse particles, discourse operators, and so on. However, DMs are most widely used. The current study adopts the term "discourse markers". DMs have a significant role to fulfill the communicative objectives of language in both spoken and written discourse. As stated by Kohlani $(2010,5)$, DMs' role in sentences is to link textual units bigger than the sentence and guide the text-receivers' interpretation of text according to the text-producers' communicative intentions.

\section{Research Questions}

This study tries to address the following questions:

- What are the problems that students face in the translation of DMs from English to Kurdish?

- Do both languages have equivalent DMs?

\section{Aims of the Study}

The present study aims to show the problems faced by the students of the Translation Department in translating DMs while translating texts from English into Kurdish.

\section{Data Collection and Procedure}

Four fourth-year students of Duhok University/ Translation Department who are Kurdish native speakers were chosen to translate the same text from English into Kurdish. The translations of the four students were checked out and the functions of DMs were identified. Then, the four translated texts were compared to show the problems students faced in choosing the correct Kurdish DMs in their texts. The translation was written by the students using the Kurdish orthographic writing system. The type of text has been chosen randomly since it contained many different DMs.

\section{The Model}

For studying and analyzing DMs, Fraser's (1999) Model has been adopted in this paper. Fraser classifies 
DMs into two main classes: propositional DMs and non-propositional DMs. These are further divided into subclasses.

\section{The Significant of the Study}

In spite of the students' realization of the importance of DMs in language, the students cannot use them well in everyday writing, which indicates that more help, guidance and instruction from teachers are needed and in terms of the students, more attention and exercises are necessary in order to obtain the automatic application of these DMs.

\section{Literature Review and the Definitions of DMs:}

DMs have been extensively and widely studied in the last two decades. Researchers have developed many approaches to be applied to this subject. Their problematic and controversial nature was investigated by Fraser (1999). He indicated that DMs are studied by different researchers under variant labels. Nevertheless, he states that researchers agree that DMs are lexical expressions that serve to relate different parts of the discourse, however, they do not agree on how to define them and what functions they have.

Schourup (1999) proposes the same. He claims that there is no agreement on the fundamental issues related to the study of DMs. Linguists are not able to decide on the grammatical category of DMs or how to identify their class or what types of meaning they have. Therefore, DMs have been defined differently by different researchers. The first definition of the term discourse marker is that of Labov and Fanshel who discussed"well" considering it as a discourse marker. They stated that any DM refers backwards to topics that already have shared knowledge among participants ( Labov and Fanshel, 1977: 932). The second definition of the term discourse marker is that by Ostman (1982, cited in Brinton, 1990 : 48 ), who points out that DMs are short items, often phonologically reduced or unstressed, which occur either outside the syntactic structure or attached to it.
Levinson (1983:87-88) refers to DMs as a unique class on their own merits and used to call them discourse "deictics" not markers. He proposes that many phrases and words are found in English which show the relation between a specific utterance and the preceding discourse. These include "however, in conclusion, therefore, but, anyway, on the contrary, still, etc. Schiffrin (1987:31) defines DMs as elements that are sequentially dependent and used to bracket units of talk. She points out that DMs mark the boundaries between the units of talk and split the text into a group of smaller units showing in addition to the relation among them.

Expressions such as "however, now, so, then, and well" are DMs according to Fraser (1990:383). They signal the sequential relation between the present message and the former discourse. DMs according to Stenstrom (1994:63) are used to mark the boundaries within the discourse, hold and organize the turn i.e., they help speakers in organizing the discourse, introducing and marking ends of topics, starting a conversation, introducing a digression, and marking a resumption of old topics. They also mark the end of a conversation. Moreover, Chalker and Weiner (1998:119) stated that DMs are words or phrases that help to signal the direction in which language, particularly in a conversation, is going. For Takahara (1998a:327), DMs are devices that mark a sequential discourse relationship to show the boundaries within the discourse and the degree of cohesion, and also decide the information flow.

In short, DMs are the most significant glue or connective element that aid the writer to create both coherence and cohesion in a text while, by the same token, they help the reader see both symmetry and stylistic consistency in the discourse he reads.

\section{Grammatical Category of DMs in English}

There is often no agreement among scholars concerning the grammatical category of DMs. For example, Zwicky (1985: 302) states that DMs form a 
unified linguistic class. In contrast, Fraser (1990: 6, 1999: 943 and 2009: 12), Brinton (1996: 34), Schourup (1999: 234) and Bazzanella (2006: 451) claim that DMs do not constitute a separate syntactic class, but are drawn primarily from different traditional categories. They constitute a heterogeneous set of forms which are difficult to place within a traditional word class. They have been variously considered as:

- Conjunctions such as (and, but, although, whereas etc).

- Adverbs (however, furthermore etc.)

- Prepositional phrases (after all, on the contrary, in spite of this/that, as a result of this/that, etc.)

\section{Functions of DMs}

Brinton (1996: 36ff) divided the function of DMs into two classes: the first set belongs to the textual mode of language and the second set belongs to the interpersonal mode of language (see Haliday and Matthiessen 2004: 30). Concerning the textual function, Brinton (1996: 37) and many other researchers state that DMs are used:

- $\quad$ to start and end discourse.

- to help the speaker take or give up the floor.

- as fillers to maintain the discourse or to hold the floor.

- to designate a fresh topic, a partial shift in topic.

- to represent either new or some old information.

- to signal a 'sequential dependence' to maintain the relevance of one clause to the preceding clause.

- to repair the discourse of a person or of the others. As for the interpersonal function, Brinton (1996: 37f.) says that DMs are used:

- $\quad$ subjectively, to express anaphoric and cataphoric discourse

- interpersonally, to achieve familiarity between speaker and addressee.

\section{Grammatical Category of DMs in Kurdish:}

In Kurdish, DMs are known as (نيشانيّن دمقى). Unlike their English counterparts, Kurdish DMs constitute a unified syntactic class, i.e. conjunctions. They are referred to as (ئامر ازيَن بها سنتىّ)

Swani (2003: 46).

\section{Conjunctions}

In Kurdish, conjunctions have been defined differently by Kurdish linguists. First of all, Emin (1960: 146) states that conjunctions are those words which are used for joining words and clauses, i.e. a conjunction is a word or a phrase that plays a connective role in language (see also Kurdfiyiv 1970: 121).

According to Wehbi (1976: 19), a conjunction is a device that links two words or a group of words together. Moreover, Swani (2003:45) points out that a conjunction is responsible for joining words, phrases, clauses and even paragraphs. Thus, types of sentences are formed by different conjunctions. .. For example (بالىّ,يان, و (and or, but) are used to join two equal clauses together to form compound sentences, whereas words like

(because, for this reason, when) link a dependent clause with an independent one to make complex sentences. Ferhadi (2008: 192) points out that the concept denoted by the word conjunction indicates connecting clauses by using some linguistic expressions that are regarded as conjunctions. In other words, combining takes place when two or more equal clauses occur together and there is a syntactic and semantic relationship between them because of the existence of a conjunction

Tewfiq (2002: 199) lists some linguistic expressions that have a connective role which are considered conjunctions. These are;

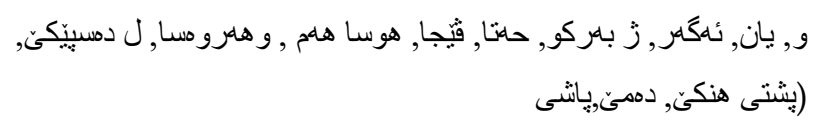

\section{Types of Conjunctions in Kurdish}

Ali (1992: 13ft) divided conjunctions in Kurdish into two classes: coordinating conjunctions and subordinating conjunctions.

\subsection{Coordinating conjunctions}

Ali (1992: 13) and Swani (2003: 52ft) define coordinators as those connectors that join two words, 
adjectives, phrases or independent clauses that are of equal status.

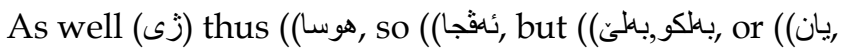
and (و), neither---nor ((بان........نهان, either ---or not only....but also (نابتتئ...بالكو هلروومان).

\subsection{Subordinating Conjunctions}

Swani (2003: 55) states that subordinating conjunctions are devices which join an independent (main or superordinate) clause with a dependent (subordinate) one.

They are as follow:

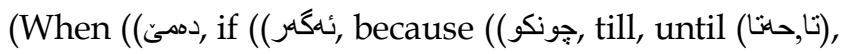

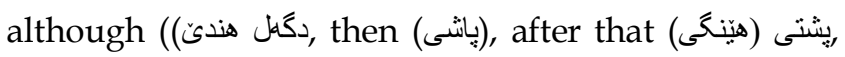

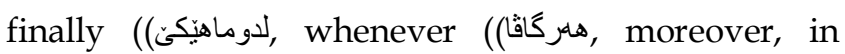

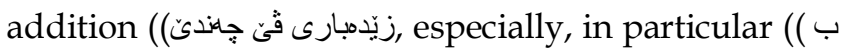

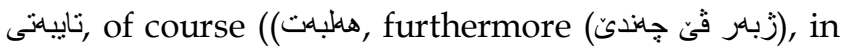

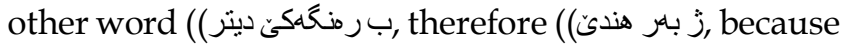

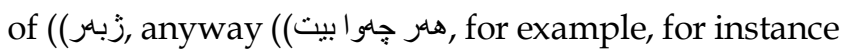
(بو نموونه), on that basis (لسامر فى بنياتى)....etc.

\section{Fraser's (1999) Model of DMs}

Fraser (1999:946ff), classifies DMs into two main categories with subclasses:

- Propositional DMs: They are used to relate the messages or the propositions together in the sentences.

- Non-Propositional DMs: They are used to mark one of the aspects of the discourse structure or of the topic like management and organization.

\subsection{Propositional DMs}

Propositional DMs have a number of subclasses; they are as follows:

A. Contrastive Markers: they refer to the contrastive aspects of the sentences.

Layla has two cars. In comparison., Susan has one.

This group includes the following expressions: (but also, on the other hand, whereas, in spite of, however, in comparison, regardless, although, on the contrary, despite, and though, conversely, nevertheless, as though, indeed, except for, even though, instead of, nonetheless, in reality, rather than, yet, alternatively, in fact, still, otherwise, in contrast, notwithstanding, though, but, even so, all the same).

\section{B. Collateral Markers}

This type shows a quasi-parallel relationship between the explicit content of segment (2) and the explicit content of segment (1).

The picnic is ruined. The food has turned rancid,

the drink is warm. Furthermore, it's raining.

This type includes: (namely, more to the point, above all, analogously, in addition, and yet, parenthetically, what is more, besides, that is to say, or, also, by the same token, to cap it all of, furthermore, equally, in particular, well, correspondingly, on top of it all, better yet, likewise, aside from, for another thing, similarly, it means, that said, and, moreover).

\section{Inferential Markers}

It marks that segment (2) is to be taken as a conclusion based on the explicit proposition of segment (1).

It's snowing. Under these conditions, we should not go to the City Center.

It consists of: (because of, so, hence, in the light of the foregoing, accordingly, at any rate, as a consequence, under these conditions, as a logical conclusion, therefore, as a result, thus, it stands to reason that, in this case, consequently, then, of course, in any event, it can be concluded that).

\section{Additional Group of Markers}

It requires that segment (2) provides a reason for the proposition presented in segment (1):

Hurry up, because we have to be there on time. This group includes the following items: (after all, because, since). 


\subsection{Non-propositional DMs}

They consist of a number of subclasses, as follow:

\section{A. Discourse Structure Markers}

These markers are used to frame the topic in terms of listing which indicates the beginning, the middle and the end of the given topic.

Finally, we will discuss the main policy implications of our findings.

They include of the following items: (once again, at the outset, finally, first/second, lastly, to start with, in the first place, next, moving right along).

\section{B. Topic Change Markers:}

These markers are used to mark that the utterance following constitutes a departure from the current topic.

I ran into Jim at the gym the other day. By the way, how is your training going? Are you still ...

This group includes: (with regard to, incidentally, to return to my point, just to update you, that reminds me of, to change the topic, before I forget, on a different note, by the way, while I think of it, back to my original point).

\section{Discourse Activity Markers:}

These markers are used to mark the writer's comment on the context of the preceding text. .

The meeting, in short, was a waste of time.

This type consists of: (in short, for instance, to illustrate, to explain, according to, for example, to interrupt, to clarify).

To answer the first question and clarify the use of DMs in this study, the following text is chosen for the analysis.

\section{"Don't Support Nuclear Energy!"}

"These days, it seems like everyone is worried about how the world will meet its energy demands when we have run out of oil and natural gas. Scientists and researchers are investigating such power sources as solar energy, wind energy and even energy from hot rocks beneath the earth's surface. However, there is one energy source that I believe should not be developed any further. In fact, I believe that we should stop it as soon as possible. Even though nuclear power can provide the world with a source of electricity, it is not a good energy source because it is too expensive, the materials used in the power plants are not safe and there is

a general possibility of accidents. Moreover, nuclear power is not an economical power energy. Nuclear fuel is expensive; therefore, it must be taken out of the ground and transported great distances. As fuels are used up, they will become even more expensive just as oil and gas have.

In addition, nuclear power plants cost a lot of money to build and operate because of the great care that must be taken with safety. Because the people who work in nuclear power plants must be highly trained specialists, salaries for workers are high.

In addition to being expensive, nuclear materials are not safe. When uranium is taken out of the ground, radioactive gas is released. This is not safe for the miners. Uranium itself is also not safe because of its high radioactivity. For this reason people who work with nuclear fuels are at risk of cancer. As nuclear power plants run, they create nuclear waste. It is very radioactive and difficult to dispose or to store safely. Thus, no town wants nuclear waste buried nearby for good reason".(Zemarch and Rumisek, 2003: 99)

Text translated by Student 1:

"بشتّفانيا وزا ئلمتومى نهكه"

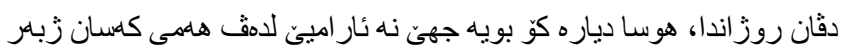

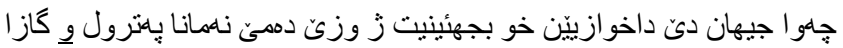

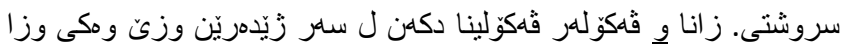

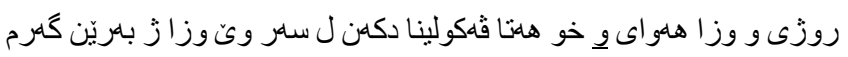

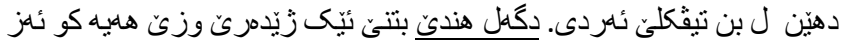

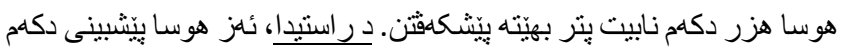

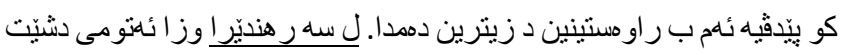

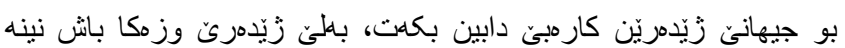

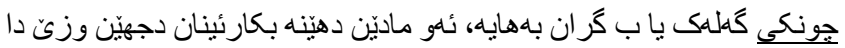




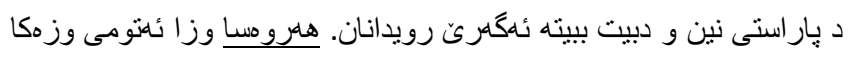

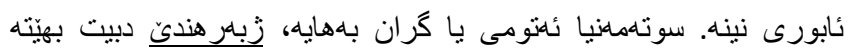

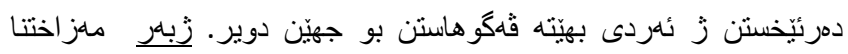

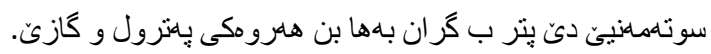

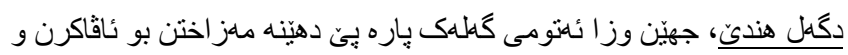

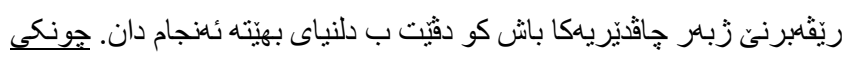

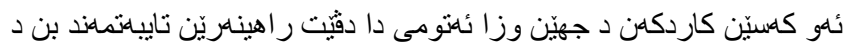

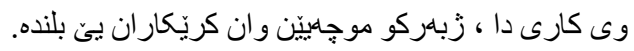

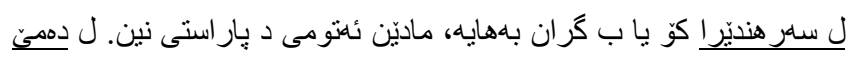

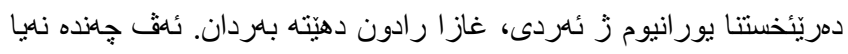

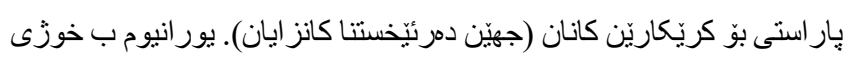

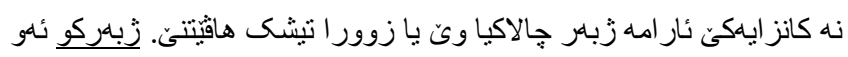

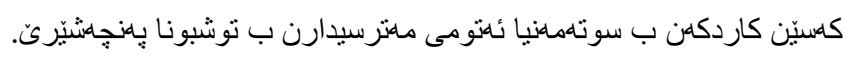

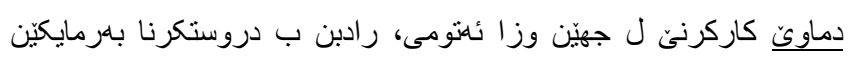

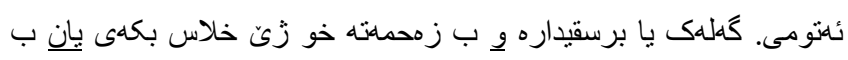

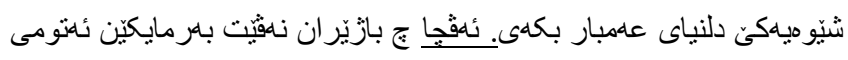

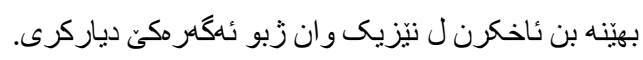

Text translated by Student 2:

"يشتخيرييا ووز ائنتو مى نهكه"

لقان ديماهييان يا دياره هلمى دخما هنديّ دانه كاديّ جيهان خو استا خو يا نهان

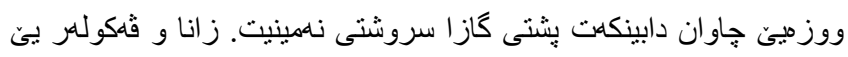

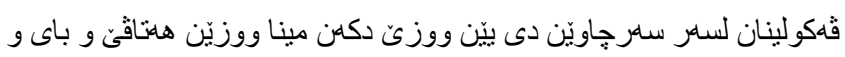

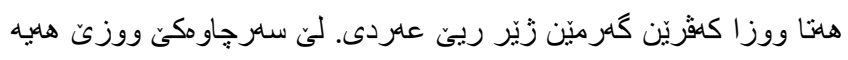

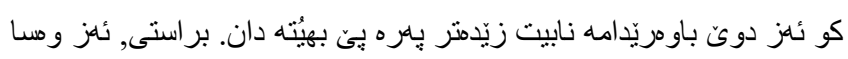

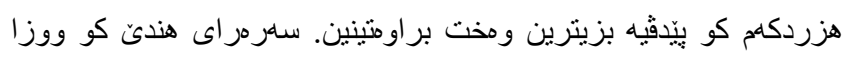

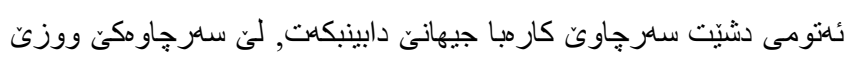

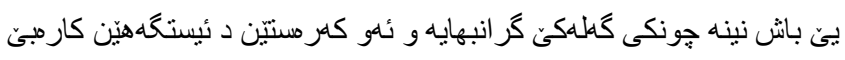

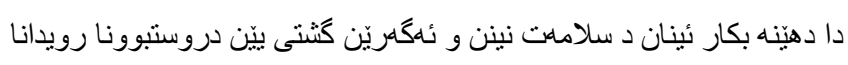

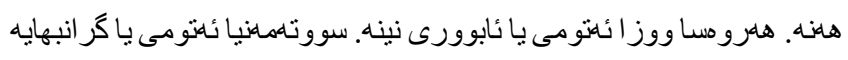

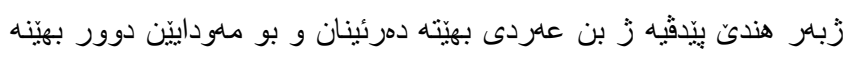

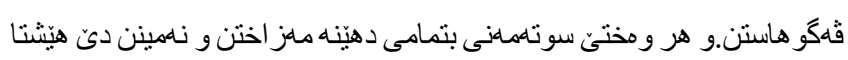

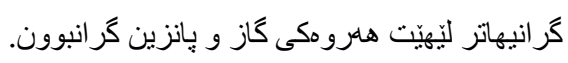

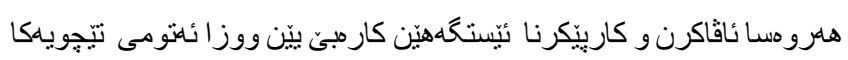

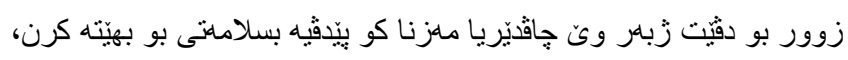

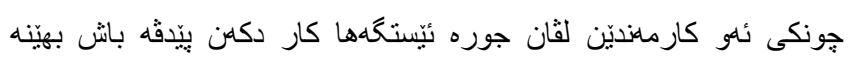

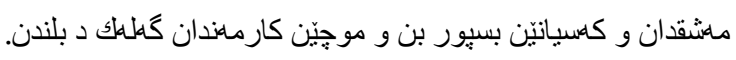

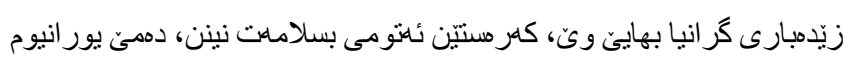

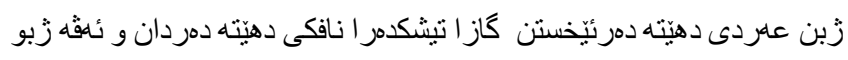

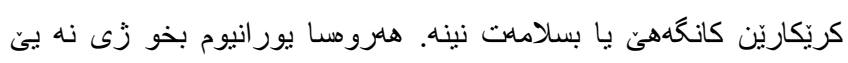

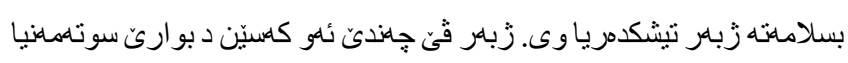

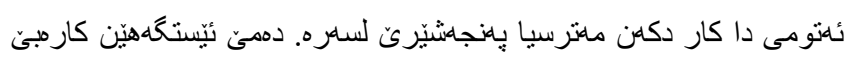

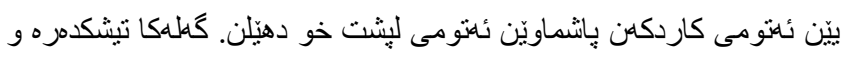

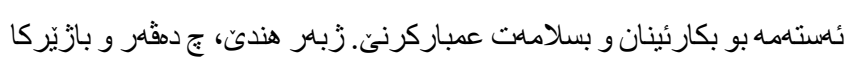

نهقثيت لدور ماندوور وان بِاشماييّن ئمتو مى بهيّنه بن ئاخ كرن. Text translated by Student 3:

"دز ايهنيا ووز ميا ئنتومى بكه"

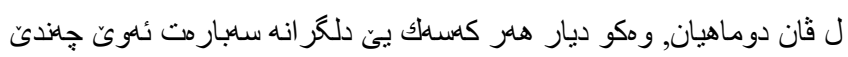

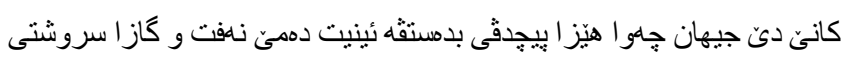

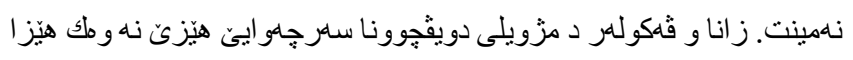

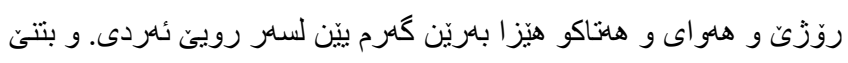

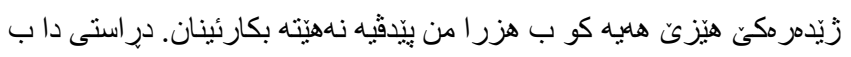

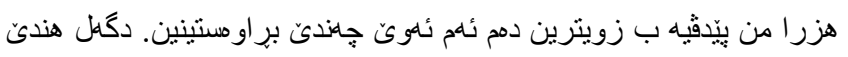

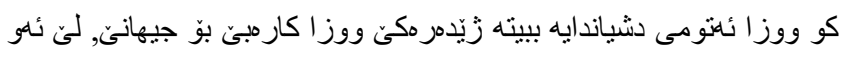

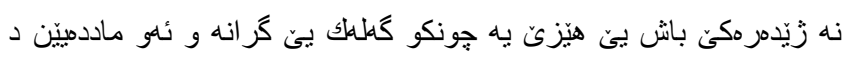

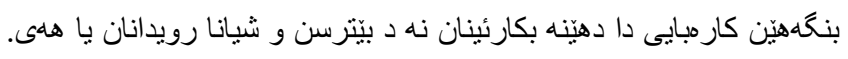

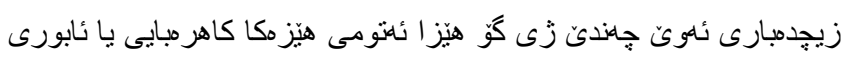

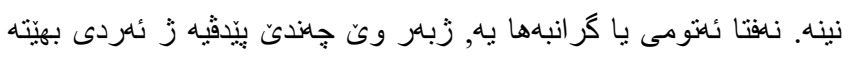

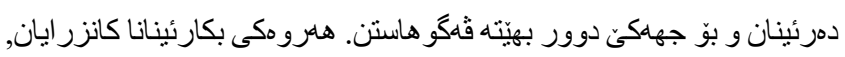

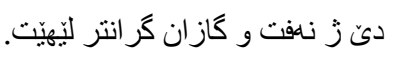

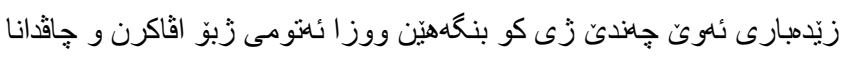

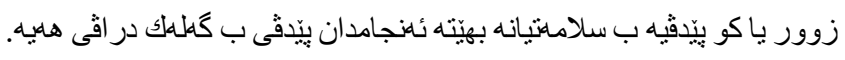

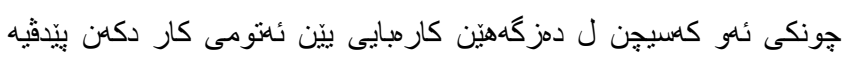

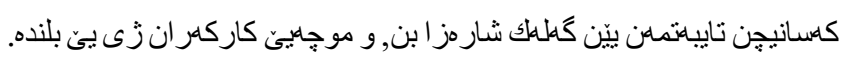

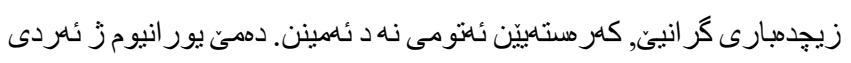

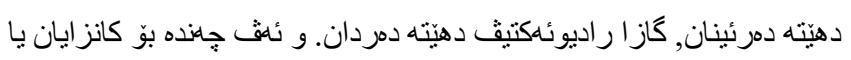

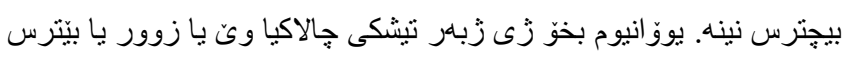

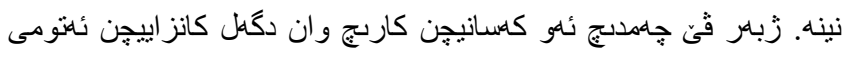

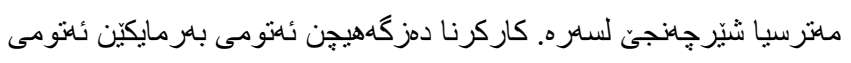

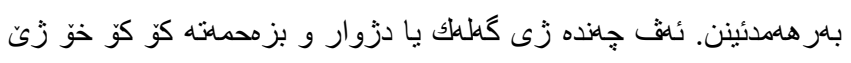

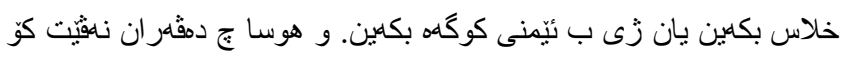

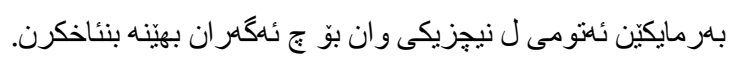
Text translated by Student 4:

"يشتهثانيا ووز ا ئلنو مى نهكه!"

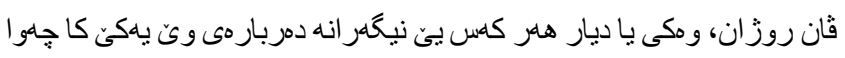

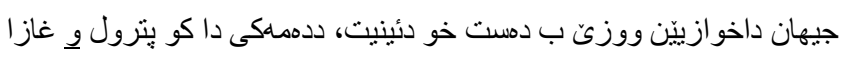

$$
\text { سروشتى نهمينيت. }
$$

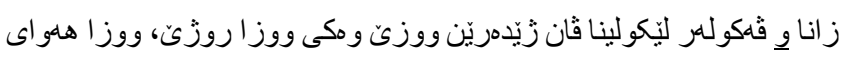

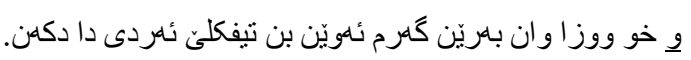

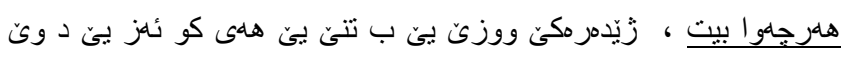

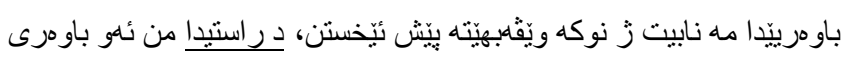

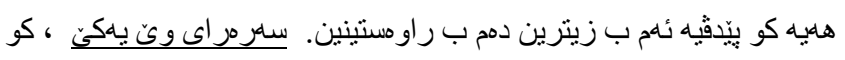

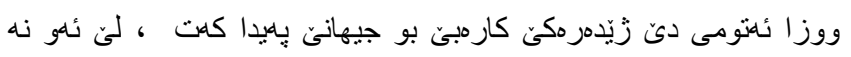

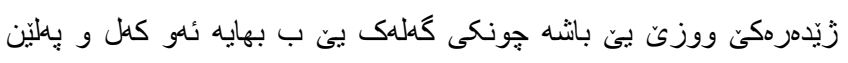

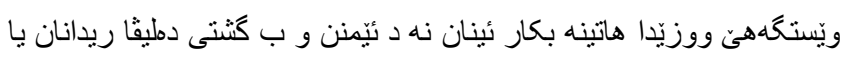

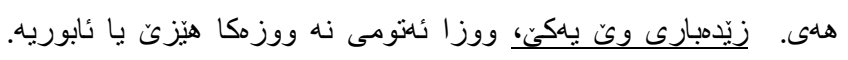

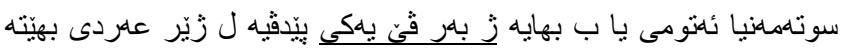




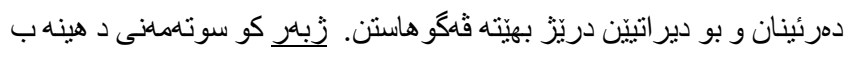

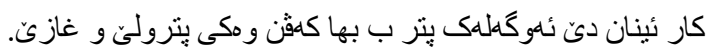

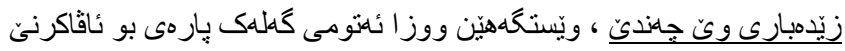

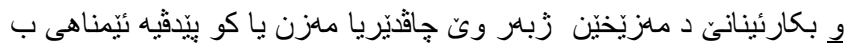
بارجاث بهيّته ومركرنن.

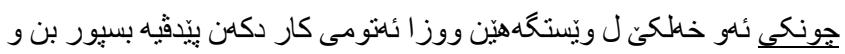

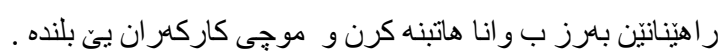

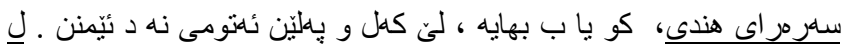

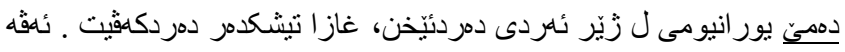

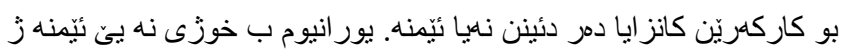

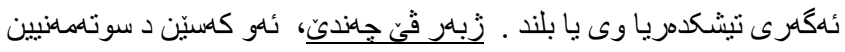

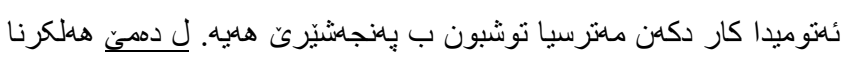

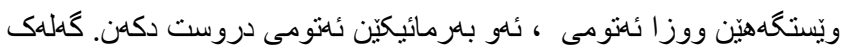

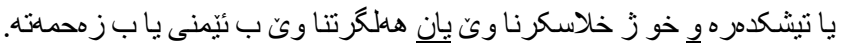

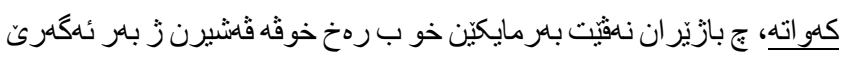
كونجاى.

\section{Discussion}

To answer the second question, the following translations of DMs are given as equivalents to the DMs which appeared in the original text:

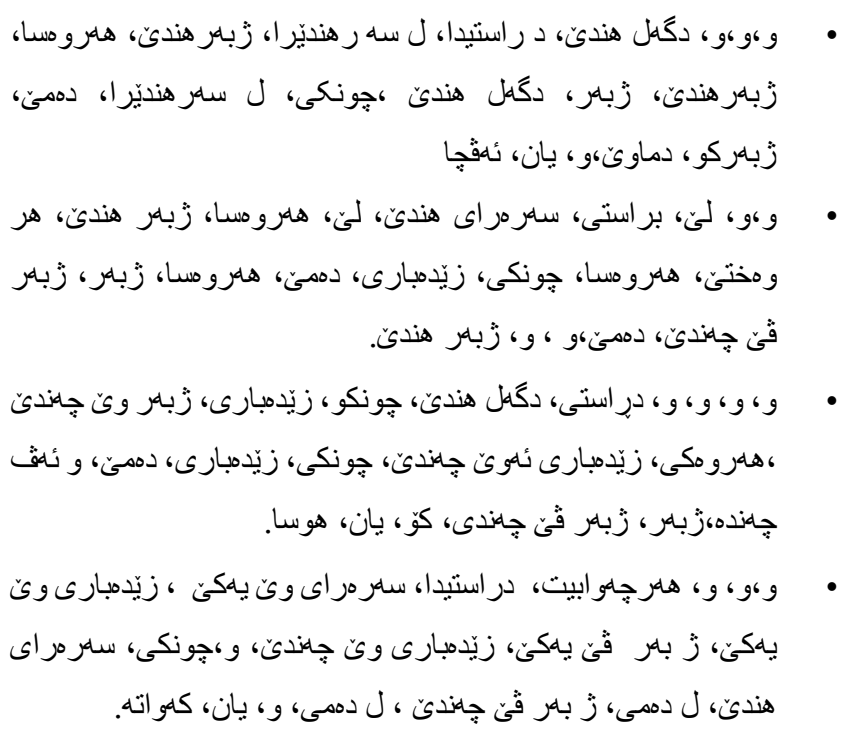

The purpose of choosing this text is that it contains different DMs (coordinate and subordinate conjunctions) and also it gives chances to the students to think, understand and then give the correct equivalent DMs in Kurdish. Also, it will answer the first question of this study (showing the difficulties students face in translating DMs from English into Kurdish).
According to the above translated DMs; most of the Kurdish versions given by the translators give different expressions for the same discourse marker in the English text. For example, for However are used. In the third translated text, the coordinator $(g)$ is used for the subordinate However which is completely un

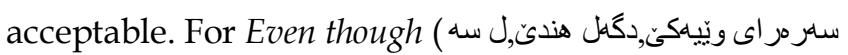
(رهنديّرا, سارمراى هندي (,) are used. The first expression which is used in the first translated text does not refer to its same meaning in English. As, in the final paragraph of the third translated text, has been omitted and translated the sentence without it which is not acceptable since the existence of that discourse marker mark as a cohesive device for the text. Others used the expressions (دمهي ل دهمى, دماوئ, ). For the coordinators (or, and) in the final paragraph, the و- يان,و - كوّ, يان- و-يان) following expressions are used 9). Here, the second translator used for both or -and the coordinator (و) which is completely wrong since (و) refers to and in English. Also, the third translator uses (ك) to refer to the coordinator and which is wrong. For thus, mixture expressions of coordinates and كة اتة. subordinates conjunctions are used which are (ئهفجا, ذبار هنديَ ,هوسا). Since thus is a coordinate conjunction, a subordinate conjunction in the second translated text (زبكر هندي) i0s used instead. Moreover, in the first translated text, the coordinator (ئقفجا) which means so, is used and this is also wrong. In reviewing the Kurdish versions given by the subjects of the study, it is noted that there is disagreement on the translation of the DMs "even though", "however", "therefore" "thus" and "so". This might be due to lack of contextual cues that help students determine the exact counterpart to a given English discourse marker. Thus, students should be aware in choosing the correct discourse marker. They need practicing and more attention and exercises are necessary in order to realize the application of these DMs So, according to the above analysis, the most 
acceptable translation for the original text in terms of

DMs is the fourth translated text.

\section{Conclusion}

According to the discussion showed above, English has a well-defined liability in using DMs more than Kurdish. The tendency of modifying what we say is a magnificent feature of western civilization and it has plentifully reflected in the use of DMs in English, written and spoken. In the translation of DMs from English into Kurdish the main problem is that of using the coordinate conjunctions instead of subordinate ones. Moreover, it is noted that the students agree in the translation of the coordinator "and" (و), while they use different expressions in the translation of subordinates. Furthermore, using the conjunctions (S) for (or, and) is another source of mistranslation. Finally, in order that the pragmatic value rather than the lexical meaning of the word is translated, it is essential that DMs are understood in respect of their function in the discourse. There are possibly some DMs in the source language that need corresponding DMs when translated into a target language in order to maintain the same conversational impact.

\section{References}

1. Bazzanella, C. (2006) DMs in Italian: Towards a Compositional Meaning. In Kerstin Fischer(ed), Approaches to discourse particles (PP449-464). Amsterdam: Elsevier.

2. Brinton, L (1996). Pragmatic Markers in English: Grammaticalization and discourse fuctions. Brlin: Mouton de Gruyter.

3. Chalker, S. and Weiner, E. (1998). The Oxford Dictionary of English Grammar Oxford: Oxford University Press.

4. Fraser, B. (1990). An approach to DMs. Journal of Pragmatics 14, 383-395.

5. Haliday, M and Matthiessen, $\mathrm{Ch}$ (2004). An introduction to the functional grammar. (3rd ed). London: Arnold.

6. Kohlani, M.A. 2010. The Function of DMs in Arabic Newspaper Opinion Articles. PhD dissertation. Washington: Georgetown University .

7. Labov, W. and Fanshel, D. (1977). Therapeutic Discourse: Psychotherapy as Conversation, New York: Academic Press

8. Levinson,S. (1983). Pragmatics, Cambridge: Cambridge University Press.

9. Östman, Jan-ola (1982). "The Symbiotic Relationship between Pragmatic Particles and Impromptu Speech".
In: N.E. Enkvist (ed.), Impromptu Speech: a Symposium (Abo: Abo Akademi), pp. 147-177.

10. Schiffrin, D. (1987). DMs, Cambridge: Cambridge University Press.

11. Schourup, L. (1999). DMs. Lingua 3(4), 227-265.

12. Stenstrom, A-B (1994). An Introduction to Spoken Interaction, London: Longman.

13. Takahara, P. (1998a). "Pragmatic Functions of DMs in English and Japanese". Selected Paper from the $6 \mathrm{lh}$ International Pragmatic Conference, (1998), pp.547-576.

14. Zemarch, A.D. Rumisek, A.L. (2003). College Writing from Paragraph to Essay. Oxford: Macmillan Education.

15. Zwicky, A (1985). Clitics and Particles. Journal of Language, vol. 61, No.2,PP.238-305.

\section{Kurdish References}

1. Ali, B. (1992). Bestin u kirtandin le Kurdida. Namey Master: Zankoy Selahedin

2. Emin, N. (1960). Rézmani Kurdi. Silémanii gapxaney Kameran.

3. Ferhadi, A. (2008). Riste u pa; riste térwaninéké erki. (eapa éké). Hewlérz dezgay gap u belawkirdinewey Aras.

4. Kurdfiyiv, K. (1982). Rézmani Kurdi be /cerestey diyalékti kirmanci. (Wergéran: Mukiryani, K.). Bexda: Eledib Elbegdadi.

5. Swani, R. (2003). Amrazi bestinewe le zimani Kurdida. Namey Ductura. Zankoy Silémani.

6. Tewfiq, Q. (2002). Peywendyekani néw deq. Namey Ductura: Zankoy Selahedin

7. Wehbi, T. (1929). Desturi zimani Kurdi. (gapa éké). 